\title{
PELAKSANAAN AKAD RAHN DI PEGADAIAN SYARIAH BERDASARKAN KOMPILASI HUKUM EKONOMI SYARIAH DI PEKANBARU
}

\author{
${ }^{1}$ Hasan Basri, ${ }^{2}$ Muhammad Azani \\ ${ }^{1,2}$ Fakultas Hukum Universitas Lancang Kuning \\ Email: ${ }^{2}$ mhd.azani@ unilak.ac.id
}

Info Artikel:

Diterima:05 November 2019 | Disetujui: 06 November 2019 |Dipublikasikan: 27 Desember 2019

Abstrak
Artikel ini menganalisis akad rahn yang dipraktikkan di pegadaian syariah. Tujuan penelitian adalah untuk menganalisis praktik rahn, hambatan, dan pemanfaatan objek rahn. Metode penelitian dengan menggunakan metode hukum sosiologis yang menganalisis berlakunya hukum dalam raktik di masyarakat. Hasil penelitian menunjukkan bahwa Pelaksanaan akad rahn Pegadaian Syariah cabang Pekanbaru dimulai saat nasabah datang langsung ke Pegadaian Syariah dengan membawa marhun. Berdasarkan taksiran yang dibuat murtahin, maka ditetapkan besarnya biaya jasa yang harus dibayarkan oleh rahin. Nasabah membayar biaya administrasi. Petugas menyimpan barang dengan baik, dan menyerahkan surat bukti penyimpanan barang kepada nasabah. Sejumlah hambatan yang ditemukan dalam akad rahn adalah a) Pembayaran Kurang Lancar dengan sebutan tunggakan hitam dan tunggakan merah. b) Pembiayaan Diragukan yaitu sisa pembiayaan atau pinjaman yang belum atau tidak dibayar setelah lebih dari tiga bulan sejak jatuh tempo lunas. Penguasaan objek rahn dalam transaksi rahn, barang gadai dikuasai oleh penerima gadai. Namun, dalam praktik terdapat juga barang gadai masih tetap dikuasai oleh pemberi gadai. Terkait dengan hal ini DSN telah menetapkan ketentuan akad gadai yang demikian dengan sebutan rahn tasjily, yakni jaminan dalam bentuk barang atas utang tetapi barang jaminan tersebut (marhun) tetap berada dalam penguasaan (pemanfaatan) rahin dan bukti kepemilikannya diserahkan kepada murtahin.

Kata Kunci: Rahn, marhun, murtahin

\section{IMPLEMENTATION OF RAHN AKAD IN SHARIA PAWN SHOPS BASED ON SHARIA ECONOMIC LAW COMPILATION IN PEKANBARU \\ Abstract}

This article analyzes the rahn contract practiced in sharia pawnshops. The research objective was to analyze the practice of rahn, barriers, and the use of rahn objects. The research method uses sociological legal methods that analyze the application of law in practice in society. The results showed that the implementation of the Pekanbaru branch of the Rahn Pegadaian Syariah contract was started when the customer came directly to the Sharia Pegadaian with a marhun. Based on the estimation made by the murtahin, it is determined the amount of service fee that must be paid by Rahin. The customer pays an administration fee. The clerk keeps the goods properly, and submits proof of storage of goods to the customer. A number of obstacles found in the rahn contract are a) Under-Current Payments, known as black arrears and red arrears. b) Doubtful Financing, namely the remaining unpaid or unpaid financing or loan after more than three months since full maturity. The control of the rahn object in a rahn transaction, the pawning item is controlled by the pawn recipient. However, in practice there are also items that are pawned which are still controlled by the pawner. In this regard, the DSN has stipulated the provisions of such a pawning contract known as rahn tasjily, namely collateral in the form of goods for debt but the collateral (marhun) remains in control (utilization) of rahin and proof of ownership is submitted to murtahin

Keywords: Rahn, marhun, murtahin 


\section{A. PENDAHULUAN}

Dewan Syariah Nasional mendefiniskan rahn dengan pengertian menahan barang sebagai jaminan atas hutang. ${ }^{1}$ Berdasarkan definisi tersebut yang mencirikan transaksi ini adalah adanya barang jaminan yang diserahkan penggadai atas hutangnya yang bilamana telah jatuh tempo tidak dapat melunasinya barang jaminan itu dapat dijual untuk melunasi hutang piutangnya. Hal ini tentu berbeda dengan transaksi hutang piutang biasa yang dalam transaksinya belum tentu ada barang sebagai jaminan atas hutang.

Konsep rahn berdasarkan fatwa DSN tentang rahn, ${ }^{2}$ dijelaskan bahwa pinjaman dengan menggadaikan barang sebagai jaminan utang dalam bentuk rahn hukumnya dibolehkan dengan ketentuan bahwa murtahin (penerima barang) mempunyai hak untuk menahan marhun (barang) sampai semua utang rahin (yang menyerahkan barang) dilunasi.

Dalam ketentuan ini ditetapkan bahwa kendatipun marhun dalam penguasaan murtahin dan sesungguhnya marhun dan manfaatnya tetap menjadi milik rahin. Dengan demikian, pada prinsipnya marhun tidak boleh dimanfaatkan oleh murtahin kecuali seizin rahin, dengan tidak mengurangi nilai

1 Fatwa Dewan Syariah Nasional Nomor 25/DSN-MUI/III/2002 tentang Rahn.

2 Fatwa Dewan Syariah Nasional Nomor 25/DSN-MUI/III/2002, ..., Loc.Cit. marhun dan pemanfaatannya itu sekedar pengganti biaya pemeliharaan dan perawatannya. $^{3}$

Tanggung jawab pemeliharaan dan penyimpanan marhun menjadi kewajiban rahin, namun dapat dilakukan juga oleh murtahin. Adapun biaya dan pemeliharaan penyimpanan tetap menjadi kewajiban rahin. Untuk menghindari dari transaksi riba karenanya besar biaya pemeliharaan dan penyimpanan marhun ditetapkan tidak boleh berdasarkan jumlah pinjaman. ${ }^{4}$

Dalam transaksi rahn telah ditetapkan batas akhir kewajiban pengembalian pinjaman. Karena itu, pada saat jatuh tempo, murtahin harus memperingatkan rahin untuk segera melunasi utangnya. Hal yang sering terjadi terkait dengan ini adalah pada saat jatuh tempo ternyata rahin tidak dapat melunasi hutangnya. Menyikapi hal ini maka marhun dapat dijual paksa/dieksekusi melalui lelang sesuai syariah. Hasil penjualannya digunakan untuk melunasi hutang, biaya pemeliharaan, biaya penyimpanan, dan biaya penjualan. ${ }^{5}$

Apabila dalam penjualan marhun dan hasil penjualannya setelah dipotong untuk pembayaran hutang dan biaya-biaya lainnya

3 Apriani, Ami. Prospek Rahn Emas di Perbankan Syariah: Studi Kasus pada Bank Syariah Mandiri, (Jakarta: UIN Jakarta, 2010), hlm 79.

${ }^{4}$ Ibid.

5 Khairiyah, Masnuatul. Analisis Perum Pergadaian Syariah Terhadap Loyalitas Konsumen: Studi Pada Pegadaian Syariah cabang Malang, (Malang: UIN Maulana Malik Ibrahim, 2010), hlm. 56. 
yang terkait dengan itu masih ada sisa maka sisanya menjadi milik rahin. Namun sebaliknya apabila hasil penjualan marhun kurang untuk membayar hutang dan biayabiaya lainnya yang terkait dengan itu maka kekurangannya menjadi kewajiban rahin untuk melunasinya.

Berdasarkan uraian di atas, analisis dalam artikel ini menganalisis beberapa rumusan masalah berikut:

1) Bagaimanakah pelaksanaan Akad Rahn Di Pegadaian Syariah Berdasarkan Kompilasi Hukum Ekonomi Syariah (KHES) Di Kota Pekanbaru?

2) Bagaimanakah hambatan pelaksanaan Akad Rahn Di Pegadaian Syariah Berdasarkan Kompilasi Hukum Ekonomi Syariah (KHES) Di Kota Pekanbaru?

3) Bagaimanakah pemanfaatan objek rahn dalam pelaksanaan Akad Rahn Di Pegadaian Syariah Berdasarkan Kompilasi Hukum Ekonomi Syariah (KHES) Di Kota Pekanbaru?

Tujuan penelitian adalah untuk menganalisis pelaksanaan, hambatan, dan pemanfaatan objek rahn dalam Akad Rahn Di Pegadaian Syariah Berdasarkan Kompilasi Hukum Ekonomi Syariah (KHES) Di Kota Pekanbaru.

\section{B. METODE PENELITIAN}

Jenis penelitian adalah penelitian hukum sosiologis yang membahas berlakunya hukum positif terkait dengan akad akad rahn di Pegadaian Syariah Cabang Pekanbaru dalam perspektif Kompilasi Hukum Ekonomi Syariah (KHES).

Lokasi penelitian ini di Pegadaian Syariah cabang Pekanbaru. Alasan dipilihnya lokasi ini adalah karena pegadaian syariah sangat diminati oleh masyarakat dalam hal akad rahn.

Populasi dan Sampel dalam penelitian terdiri atas:

1) Pegadaian Syariah cabang Pekanbaru

2) Petugas penaksir emas( Penaksir Madya).

3) Nasabah akad rahn Pegadaian Syariah Syariah cabang Pekanbaru periode 2019-2020

Sampel yang ditetapkan dalam pengumpulan data adalah sebagai berikut:

1) Kepala Cabang Pegadaian Syariah cabang Pekanbaru berjumlah 1 orang

2) Petugas penaksir emas (Penaksir Madya) berjumlah 1 orang

3) Nasabah akad rahn Pegadaian Syariah cabang Pekanbaru periode 2019-2020 berjumlah 2 orang. 
Sumber Data yang digunakan diuraikan dalam 3 (tiga) jenis data sebagai berikut:

1) Data primer, yakni data yang diperoleh dari responden di lapangan

2) Data sekunder, yakni data yang diperoleh dari berbagai referensi yang terkait dengan permasalahan penelitian

3) Data tertier, yakni data yang diperoleh dari kamus hukum dan ensiklopedi hokum.

Teknik Pengumpulan Data menggunakan 2 (dua) pola:

1) Wawancara non-struktur, yakni wawancara bebas tanpa terikat dengan daftar pertanyaan.

2) Kajian dokukemtasi, yakni mengkaji berbagai akad akad rahn dan referensi yang terkait dengan permasalahan.

Setelah data terkumpul selanjutnya diklasifikasikan dalam dua kelompok. Kelompok pertama data yang diperoleh dari hasi wawancara dan studi dokumentasi dianalisis dengan metode kualitatif sedangkan data hasil kuisioner ditabulasikan dan dianalisis dengan metode kuantitatif. Untuk mengambil kesimpulan digunakan metode induktif, yakni menarik kesimpulan dari pernyataan yang bersifat khusus ke dalam pernyataan yang bersifat umum.

\section{HASIL DAN PEMBAHASAN}

Hasil penelitian menyatakan bahwa pelaksanaan akad rahn Pegadaian Syariah cabang Pekanbaru dimulai saat nasabah datang langsung ke Pegadaian Syariah dengan membawa marhun. Kemudian mengisi formulir permintaan jasa penitipan, dan melengkapinya dengan foto copy KTP atau identitas lain yang masih berlaku atau surat kuasa apabila pemilik barang tidak dapat datang sendiri; Petugas menerima, memeriksa, dan menghitung nilai marhun yang akan dititipkan. Berdasarkan taksiran yang dibuat murtahin, maka ditetapkan besarnya biaya jasa yang harus dibayarkan oleh rahin. Nasabah membayar biaya administrasi. Petugas menyimpan barang dengan baik, dan menyerahkan surat bukti penyimpanan barang kepada nasabah.

Sejumlah hambatan yang ditemukan dalam akad rahn adalah a) Pembayaran Kurang Lancar dengan sebutan tunggakan hitam dan tunggakan merah. b) Pembiayaan Diragukan yaitu sisa pembiayaan atau pinjaman yang belum atau tidak dibayar setelah lebih dari tiga bulan sejak jatuh tempo lunas, tetapi pembiayaan masih dapat diselamatkan dan agunan bernilai $75 \%$ dari utang nasabah dan Pembiayaan tidak dapat diselamatkan tetapi agunan masih bernilai sekurang-kurangnya $100 \%$ dari utang nasabah. c) Pembiayaan macet yaitu sisa pembiayaan yang tidak memenuhi kriteria lancar, kurang lancar 
dan diragukan seperti tersebut di atas, atau, Memenuhi kriteria diragukan seperti disebut di atas, tetapi dalam jangka waktu 4 bulan sejak digolongkan diragukan belum ada pelunasan atau usaha penyelamatan pembiayaan, dan pembiayaan tersebut penyelesaianya melaui prosedur Basyarnas dan bersifat mengikat bagi para pihak.

Kebiasaan dalam transaksi gadai, barang gadai dikuasai oleh penerima gadai. Namun, dalam praktik terdapat juga barang gadai masih tetap dikuasai oleh pemberi gadai. Terkait dengan hal ini DSN telah menetapkan ketentuan akad gadai yang demikian dengan sebutan rahn tasjily, yakni jaminan dalam bentuk barang atas utang tetapi barang jaminan tersebut (marhun) tetap berada dalam penguasaan (pemanfaatan) rahin dan bukti kepemilikannya diserahkan kepada murtahin.

\section{Pelaksanaan Akad Rahn Di} Pegadaian Syariah Berdasarkan Kompilasi Hukum Ekonomi Syariah (KHES) Di Kota Pekanbaru

Prosedur layanan jasa akad rahn Pegadaian Syariah cabang Pekanbaru dapat diuraikan sebagai berikut ini:

a) Nasabah datang langsung ke Pegadaian Syariah dengan membawa marhun. Kemudian mengisi formulir permintaan jasa penitipan, dan melengkapinya dengan foto copy KTP atau identitas lain yang masih berlaku atau surat kuasa apabila pemilik barang tidak dapat datang sendiri;

b) Petugas menerima, memeriksa, dan menghitung nilai marhun yang akan dititipkan. Berdasarkan taksiran yang dibuat murtahin, maka ditetapkan besarnya biaya jasa yang harus dibayarkan oleh rahin.

c) Nasabah membayar biaya administrasi.

d) Petugas menyimpan barang dengan baik, dan menyerahkan surat bukti penyimpanan barang kepada nasabah.

Prosedur di atas merupakan kesimpulan pengamatan penulis pada aktivitas akad rahn dengan sistem syariah oleh nasabah dan pihak Pegadaian Syariah cabag Pekanbaru. Prosedur yang paling menentukan bagi nasabah sebetulnya pada poin 2 tentang nilai taksiran oleh petugas Penaksir Madya. Hasil analisis petugas Penaksir Madya memberikan kesimpulan final akan kelayakan emas yang digadaikan dan nasabah mendapat dana yang diinginkan.

Dalam perspektif KHES, pihak Pegadaian Syariah sudah dapat menahan barang yang digadaikan setelah terjadi akad antara kedua pihak. ${ }^{6}$ Pihak Bank

${ }^{6}$ Rahmat Syafei, Konsep Gadai; Ar-Rahn dalam Fikih Islam antara Nilai Sosial dan Nilai 
telah sah menyandera sejumlah harta yang diserahkan sebagai jaminan secara hak, dan dapat diambil kembali sejumlah harta dimaksud sesudah ditebus. ${ }^{7}$

Pada Akad Rahn, nasabah (rahin) menyepakati untuk menyimpan barangnya (marhun) kepada murtahin Pegadaian Syariah cabang Pekanbaru. Pelaksanaan Akad Rahn dapat dijelaskan sebagai berikut:

a) Murtahin melakukan pemeriksaan termasuk menaksir harga marhun;

b) Setelah semua persyaratan terpenuhi, maka murtahin dan nasabah (rahin) akan melakukan akad;

c) Setelah akad dilakukan, murtahin akan memberikan sejumlah marhun bih (pinjaman) yang dinginkan oleh nasabah (rahin) dimana jumlahnya disesuaikan dengan nilai taksir barang (di bawah nilai jaminan);

d) Biaya administrasi dan biaya perawatan, maka pada saat melunasi marhun bih (pinjaman), maka nasabah (rahin) akan memberikan sejumlah ongkos kepada murtahin.

Mengacu pada Fatwa Dewan Syariah Nasional Majelis Ulama Indonesia No: 09/DSNMUI/IV/2000 tentang Pembiayaan

Komersial dalam Huzaimah T. Yanggo, Problematika Hukum Islam Kontemporer III, Jakarta: Lembaga Studi Islam dan Kemasyarakatan, 1995), hlm. 59.

7 Sutan Remi Sjahdeni, Perbankan Syariah: Produk-produk dan Aspek Hukumnya, (Jakarta: Jayakarta Agung Offset, 2010), hlm. 59.
Ijarah ongkos perawatan barang titipan dibolehkan. Biaya administrasi beragam tergantung besaran pinjaman dan emas yang digadaikan.

Wawancara penulis dengan Petugas Penaksir Madya Akad rahn Pegadaian Syariah cabang Pekanbaru:

Uang adminstrasi yang ditanggung nasabah bervariasi tergantung berat emas dan dana yang dipinjam. Kita hanya menerima emas minila 2 gram. Minimal emas 2 gram sampai 50 gram ongkos adminsitrasi kita kenakan Rp. 20.000,00., Emas 50 gram -100 gram ongkos administrasi sebesar Rp. 40.000,00., Emas seberat 100 gram 250 gram dikenakan ongkos Rp. 75.000,00., Emas di atas > 250 gram hingga pinjaman Rp. 250.000.000,00., dikenakan biaya administrasi Rp. 100.000,00.,.

Biaya adminstrasi harus dibayar di awal transaksi. Namun biaya jasa titipan barang/emas dibayar saat nasabah melunasi pinjaman Pegadaian Syariah cabang Pekanbaru:

Istilah jasa titip yang kita gunakan dibayarkan di akhir pelunasan pinjaman. Ini yang beralaku di Pegadaian Syariah cabang Pekanbaru. Di tempat lain, ongkos jasa titip ini memang berbeda-beda mekanismenya. Bank Riau Kepri misalnya, unit Syariah menerapkan 
bahwa jasa penitipan langsung dipotong diawal ketika terjadi kesepakatan jumlah dana yang disetujui oleh pihak bank. Jika dihitung, model seperti ini mengurangi penerimaan dana nasabah. $^{8}$

Proses pengembalian pinjaman (marhun bih) sampai penerimaan barang jaminan tidak dikenakan biaya apapun, kecuali membayar jasa penyimpanan (ijarah) sesuai tarif yang berlaku. Pelunasan uang pinjaman (marhun bih) dapat dilakukan dengan beberapa cara: Pelunasan pokok pinjaman (marhun bih), barang jaminan (marhun) yang dikuasai oleh mutarhin dikembalikan kepada nasabah (rahin) sesuai dengan tarif yang telah ditetapkan; Pelunasan pinjaman dapat juga dilakukan dengan cara menjual barang jaminan (marhun) jika nasabah (rahin) tidak dapat memenuhi kewajibannya setelah jatuh tempo. Hasil penjualan (lelang) barang jaminan (marhun) digunakan untuk melunasi dan membayar jasa penyimpanan serta biaya-biaya yang timbul atas penjualan (lelang) barang tersebut. $^{9}$

Harga jual barang jaminan (marhun) melebihi kewajiban nasabah (rahin) maka

\footnotetext{
${ }^{8}$ Hasil wawancara dengan Petugas Penaksir Madya Akad rahn Pegadaian Syariah cabang Pekanbaru.

9 Akad Gadai Sertifikat Gadai Syariah di Pegadaian Syariah.
}

sisanya dikembalikan kepada nasabah (rahin). Jika jumlah penjualan barang ternyata tidak mencukupi pokok pinjaman (marhun bih) dan membayar jasa penyimpanan maka kekurangannya tetap menjadi kewajiban nasabah (rahin) untuk membayar atau melunasinya. ${ }^{10}$

Nasabah (rahin) dapat memilih skim pelunasan, apakah melunasi secara sekaligus atau dengan cicilan. Selain itu, jika dalam masa 4 (empat) bulan nasabah (rahin) belum dapat melunasi kewajibannya, maka ia dapat mengajukan permohonan perpanjangan jangka waktu pinjaman baru untuk masa 4 bulan berikutnya beserta biaya yang harus ditanggungnya dan membuat akad baru. Jika setelah perpanjangan masa pelunasan pemberi gadai (rahin) tidak dapat melunasinya kembali, maka barang gadai (marhun) akan dijual oleh murtahin. ${ }^{11}$

Nasabah yang tidak dapat melunasi pinjamannya, maka pegadaian syariah dapat memberikan kesempatan kepada nasabah untuk melakukan gadai ulang atau melakukan perpanjangan gadai. Nasabah yang telah diberi kesempatan untuk memperpanjang pembiayaannya tetapi tidak dapat juga melunasi utangnya, maka

\footnotetext{
${ }^{10}$ Prasetyo, Dodi. Praktik Akad rahn di Bank BNI Syariah cabang Surabaya, (Surabaya: IAIN Sunan Ampel, 2009), hlm. 97.

${ }^{11}$ Hasil wawancara dengan Petugas Penaksir Madya Akad rahn Pegadaian Syariah cabang Pekanbaru.
} 
pelunasannya dilakukan dengan cara penjualan barang jaminan. Cara yang ditempuh pihak pegadaian syariah adalah legal karena dalam akta aka dhal tersbut telah menjadi kesepakatan para pihak yang melakukan akad. ${ }^{12}$

Penjualan barang jaminan adalah suatu proses penjualan barang jaminan untuk melunasi pembiayaan nasabah dalam hal nasabah tidak dapat melunasi pembiayaan hingga saat jatuh tempo dan Bank tidak memperpanjang pembiayaan tersebut, dapat dilakukan dengan langkahlangkah/ketentuan sebagai berikut: Minimal 1 (satu) hari sebelum penjualan barang jaminan, Penaksir bersama kepala Pegadaian Syariah cabag Pekanbaru harus melakukan penaksiran ulang guna menetapkan harga dasar penjualan dengan mengacu kepada Standar Takaran Logam Emas (S.T.L.E); Namun demikian, setiap Cabang diberikan kewenangan untuk menjual barang sesuai harga pasar setempat dengan allowance sebesar +/- 2\%; Harga dasar penjualan sudah termasuk nilai pembiayaan nasabah dan biaya-biaya yang mungkin timbul dalam proses penjualan barang jaminan; Penaksir menyampaikan

\footnotetext{
12 Susilowati, Tri Pudji. Pelaksanaan Gadai dengan Sistem Syariah di Perum Pegadaian Semarang, (Semarang: Universitas Diponegoro, 2008), hlm. 138-139.
}

Surat Pemberitahuan Hasil Penjualan Barang Jaminan kepada nasabah. ${ }^{13}$

\section{Hambatan pelaksanaan Akad Rahn Di Pegadaian Syariah Berdasarkan} Kompilasi Hukum Ekonomi Syariah (KHES) Di Kota Pekanbaru

Terhadap nasabah yang membayar angsuran terlambat atau menunggak maka langkah awal yang dilakukan Pegadaian Syariah syariah cabang Pekanbaru adalah mengunjungi nasabah. Apabila nasabah yang menunggak cukup banyak, skala prioritas berdasarkan adanya pemasukan atau pembayaran tunggakan oleh nasabah:

\section{a. Pembayaran Kurang Lancar}

Tunggakan Hitam yaitu pembiayaan yang pembayaran angsurannya baik satu atau lebih belum dibayar sampai dengan saat akhir bulan masa angsuran tersebut, tetapi belum melewati batas waktu pelunasan (jatuh tempo lunas) jadi atas nasabah yang demikian maka setiap kali terjadi tunggakan segera dikunjungi untuk mengetahui sebab-sebab menunggak serta mengingatkan yang bersangkutan agar segera membayar.

Tunggakan Merah yaitu pembiayaan atau sisa pembiayaan yang belum dibayar sesudah akhir bulan batas waktu pelunasan (jatuh tempo lunas), namun belum melebihi tiga bulan batas waktu pelunasannya.

\footnotetext{
${ }^{13}$ Hasil wawancara dengan Petugas Penaksir
} Madya Akad rahn Pegadaian Syariah cabang Pekanbaru. 
Terhadap nasabah yang demikian setiap bulan pihak Bank mengunjungi dengan minta janji kesanggupan dari nasabah kapan akan membayar utangnya. ${ }^{14}$

\section{b. Pembiayaan Diragukan}

Pembiayaan diragukan yaitu sisa pembiayaan atau pinjaman yang belum atau tidak dibayar setelah lebih dari tiga bulan sejak jatuh tempo lunas, tetapi berdasarkan penilaian dapat disimpulkan bahwa:

1) Pembiayaan masih dapat diselamatkan dan agunan bernilai $75 \%$ dari utang nasabah.

2) Pembiayaan tidak dapat diselamatkan tetapi agunan masih bernilai sekurangkurangnya $100 \%$ dari utang nasabah.

\section{c. Pembiayaan Macet}

Pembiayaan macet yaitu sisa pembiayaan yang; Tidak memenuhi kriteria lancar, kurang lancar dan diragukan seperti tersebut di atas, atau memenuhi kriteria diragukan seperti disebut di atas, tetapi dalam jangka waktu 4 bulan sejak digolongkan diragukan belum ada pelunasan atau usaha penyelamatan pembiayaan.

Pembiayaan tersebut penyelesaianya melaui prosedur Basyarnas dan bersifat mengikat bagi para pihak . (Akad Gadai/Rahn poin 11 dalam Serifikat Gadai Syariah).

${ }^{14}$ Hasil wawancara dengan Petugas Penaksir Madya Akad rahn Pegadaian Syariah cabang Pekanbaru.
Nasabah diberi kesempatan untuk menjual sendiri barang jaminannya dalam artian bahwa nasabah mencari pihak ketiga yang hendak membeli barang jaminannya guna pelunasannya utangnya.

Pihak pegadaian syariah melihat nilai historis yang dimiliki dari barang jaminan emas tersebut, yaitu perhiasan emas yang mungkin diperoleh dari hasil warisan secara turun-temurun atau dari sumber lainnya. Jika nasabah tidak dapat menjual sendiri kepada pihak ketiga, maka pihak Bank yang akan menjual barang jaminan tersebut pada tempat penjualan emas berdasarkan harga pasar, dan uang hasil penjualan barang jaminan tersebut digunakan Bank untuk membayar/melunasi utang nasabah kepada Bank setelah dikurangi biaya-biaya yang timbul atas penjualan barang jaminan. ${ }^{15}$

Perselisihan atau permasalahan dalam pelaksanaan gadai Pegadaian Syariah cabang Pekanbaru, pihak Bank menyelesaikan secara silaturrahmi dan kekeluargaan. Karena pada dasarnya pembiayaan yang diberikan oleh pihak Bank kepada nasabahnya didasarkan pada prinsip kepercayaan (trust). Tetapi apabila nasabah tidak melakukan pembayaran utangnya pada saat jatuh tempo kepada Bank, maka pihak Bank akan

\footnotetext{
${ }^{15}$ Hasil wawancara dengan Petugas Penaksir Madya Akad rahn Pegadaian Syariah cabang Pekanbaru.
} 
menjual/menyuruh menjual barang jaminan tersebut untuk pelunasan utang nasabah dan sisa dari hasil penjualan barang agunan tersebut akan diserahkan kepada nasabah. ${ }^{16}$

Dalam menangani nasabah yang tidak melaksanakan kewajibannya, terlebih dahulu mengunjungi nasabah dan memberikan teguran-teguran.

Semuanya dilakukan dalam suasana silaturrahmi dan kekeluargaan. Apabila nasabah tidak juga membayar maka diberi kesempatan kepada nasabah untuk menjual sendiri barang agunannya untuk melunasai utangnya atau dari sumber lain. Apabila nasabah tidak dapat atau tidak mau membayar utangnya dengan cara menjual sendiri barang agunannya atau dari sumber lainnya dan menjual barang agunan tersebut dan sisanya akan diserahkan kepada nasabah. Pegadaian Syariah cabang Pekanbaru tidak menempuh jalur hukum dalam menangani nasabah yang tidak melaksanakan kewajibannya. Penyelesaian melalui pengadilan membutuhkan waktu yang lama dan biaya yang besar, sedangkan pada umumnya nasabah yang mengajukan permohonan pembiayaan kepada Pegadaian Syariah cabang Pekanbaru adalah pengusaha kecil. ${ }^{17}$

\footnotetext{
16 Akad Gadai/Rahn poin 5 dan 6 dalam Serifikat Gadai Syariah.

${ }^{17}$ Hasil wawancara dengan Petugas Penaksir Madya Akad rahn Pegadaian Syariah cabang Pekanbaru.
}

\section{Pemanfaatan Objek Rahn dalam} pelaksanaan Akad Rahn Di Pegadaian Syariah Berdasarkan Kompilasi Hukum Ekonomi Syariah (KHES) Di Kota Pekanbaru

Kebiasaan dalam transaksi gadai, barang gadai dikuasai oleh penerima gadai. Namun, dalam praktik terdapat juga barang gadai masih tetap dikuasai oleh pemberi gadai. Terkait dengan hal ini DSN telah menetapkan ketentuan akad gadai yang demikian dengan sebutan rahn tasjily, yakni jaminan dalam bentuk barang atas utang tetapi barang jaminan tersebut (marhun) tetap berada dalam penguasaan (pemanfaatan) rahin dan bukti kepemilikannya diserahkan kepada murtahin.

Dalam fatwanya ditentukan bahwa pinjaman dengan menggadaikan barang sebagai jaminan hutang dalam bentuk rahn tasjily dibolehkan dengan ketentuan bahwa rahin diwajibkan menyerahkan bukti kepemilikan barang kepada murtahin. Penyimpanan barang jaminan dalam bentuk bukti sah kepemilikan atau sertifikat tersebut tidak memindahkan kepemilikan barang ke murtahin. Apabila terjadi wanprestasi atau tidak dapat melunasi utangnya, marhun dapat dijual paksa/dieksekusi langsung baik melalui lelang atau dijual ke pihak lain sesuai prinsip syariah. Rahin memberikan 
wewenang kepada murtahin untuk mengeksekusi barang tersebut apabila terjadi wanprestasi atau tidak dapat melunasi utangnya. Pemanfaatan barang marhun oleh rahin harus dalam batas kewajaran sesuai kesepakatan. Murtahin dapat mengenakan biaya pemeliharaan dan penyimpanan barang marhun (berupa bukti sah kepemilikan atau sertifikat) yang ditanggung oleh rahin. Besaran biaya pemeliharaan dan penyimpanan barang marhun tidak boleh dikaitkan dengan jumlah pinjaman yang diberikan. Besaran biaya pemeliharaan dan penyimpanan barang tersebut didasarkan pada pengeluaran yang riil dan beban lainnya berdasarkan akad ijarah. Biaya asuransi pembiayaan rahn tasjily ditanggung oleh Rahin. $^{18}$

Dalam transaksi gadai berdasarkan KHES, suatu harta dan segala sesuatu yang termasuk di dalamnya statusnya adalah sebagai barang yang digadaikan. Harta gadai dapat diganti dengan harta gadai yang lain berdasarkan kesepakatan kedua belah pihak. Termasuk juga dalam hal masalah hutang, hutang yang dijamin oleh harta gadai dapat ditambah secara sah dengan jaminan harta gadai yang sama. Setiap

18 Fatwa Dewan Syariah Nasional Nomor 68/DSN-MUI/III2008 tentang Rahn Tasjily tambahan dari harta gadai merupakan bagian dari harta gadai asal. ${ }^{19}$

Dalam hal harta gadai sudah dikuasai oleh penerima gadai, maka akad gadai tidak dapat dibatalkan kecuali adanya persetujuan dari penerima gadai. Namun apabila belum dikuasainya akad gadai dapat dibatalkan. Berdasarkan kehendaknya sendiri penerima gadai dapat membatalkan akad gadainya. Ketika terjadinya pembatalan akad gadai penerima gadai boleh menahan harta gadai setelah pembatalan akad gadai sampai hutang yang dijamin oleh harta gadai itu dibayar lunas. Akad gadai tidak batal karena pemberi gadai atau penerima gadai meninggal. Termasuk apabila pemberi gadai meninggal dunia dalam keadaan pailit, pinjaman tersebut tetap berada dalam status harta gadai. Ahli waris dari pemberi gadai dapat menebus harta itu dengan cara membayar hutangnya. Apabila ahli waris penerima gadai tidak melunasi hutang pewaris, maka penerima gadai dibolehkan menjual harta gadai untuk melunasi hutang pewaris. Hasil penjualan barang gadai yang melebihi hutangnya, kelebihannya wajib dikembalikan kepada ahli waris dari pemberi gadai. Demikian pula apabila hasil penjualan harta gadai tidak cukup untuk melunasi hutang pemberi gadai, maka

\footnotetext{
${ }^{19}$ Peraturan Mahkamah Agung No. 2 Tahun 2008 ..., Op. Cit. Pasal 333-336.
} 
penerima gadai berhak menuntut pelunasan hutang tersebut kepada ahli warisnya. ${ }^{20}$

Harta pinjaman sesungguhnya tidak dapat digadaikan kecuali mendapat izin dari pihak yang memiliki harta itu. Dengan adanya izin itu seseorang boleh menggadaikan dengan cara apapun sepanjang pemilik harta tersebut memberi izin tanpa syarat apapun. Sebaliknya apabila pemilik harta itu memberi izin dengan syarat, maka peminjam tidak boleh menggadaikan harta tersebut kecuali sesuai dengan persyaratan yang telah disepakati. Apabila seseorang meminjamkan harta dan harta itu kemudian digadaikan oleh peminjam dengan seizinnya, maka pemilik harta tidak berhak menuntut harta tersebut dari penerima gadai sampai hutang yang dijamin oleh harta gadai itu dilunasi walaupun sudah meninggal. Dalam kaitan dengan izin, barang yang dalam status digadaikan dapat digadaikan kembali dengan pihak ketiga sepanjang mendapat izin dari pihak lainnya bilamana tanpa izinnya maka akad gadai itu dinyatakan batal. $^{21}$

Adanya akad rahn menimbulkan hak dan kewajiban antarpihak. Hak penerima gadai adalah menahan harta gadai sampai hutang pemberi gadai dibayar lunas. Jika pemberi gadai meninggal, maka penerima gadai mempunyai hak istimewa dari pihak- pihak yang lain dan boleh mendapat pembayaran hutang dari harta gadai itu. Kendatipun sudah meningal bukan berarti menghilangkan hak penerima gadai untuk menuntut pembayaran hutangnya. Apabila pemberi gadai meninggal dunia ahli waris yang memiliki kecakapan hukum dapat menggantikan statusnya sebagai pemberi gadai. Wali dari ahli waris yang tidak cakap hukum pemberi gadai yang meninggal dapat menjual harta gadai setelah mendapat izin terlebih dahulu dari penerima harta gadai, lalu membayar hutang pemberi gadai. Pemberi gadai mempunyai hak untuk menerima atau menolak akad jual beli yang dilakukan oleh penerima gadai jika penerima gadai menjual harta gadai tanpa izinnya. Demikian pula halnya dengan peminjaman harta gadai kepada pihak ketiga, hal ini dapat dilakukan apabila pemberi dan penerima gadai menyepakatinya. ${ }^{22}$

Harta yang telah digadaikan tidak boleh digunakan atau dimanfaatkan oleh penerima gadai. Penggunaan atau pemanfaatan harta gadai dibolehkan apabila mendapat izin dari pemberi gadai. Fatwa DSN menekankan bahwa penggunaan atau pemanfaatan harta gadai dibolehkan sepanjang tidak mengurangi nilai marhun

\footnotetext{
${ }^{20}$ Ibid., Pasal 340, 346, 350-352.

${ }^{21}$ Ibid., Pasal 342.
}

${ }^{22}$ Ibid., Pasal 343, 347-348, 355-356. 
dan pemanfaatannya itu sekedar pengganti biaya pemeliharaan dan perawatannya. ${ }^{23}$

Tanggung jawab penyimpanan harta gadai melekat pada pihak penerima gadai atau pihak ketiga yang telah disepakati. Pengadilan dapat menunjuk penyimpan harta gadai jika pemberi dan penerima gadai tidak sepakat. Dalam hal harta gadai disimpan oleh pihak ketiga, harta tersebut tidak boleh diserahkan kepada pemberi gadai maupun kepada penerima gadai tanpa izin dari salah satu pihak. Biaya penyimpanan dan pemeliharaan harta gadai menjadi tanggung jawab pemberi gadai kecuali ditentukan lain dalam akad. Pihak penyimpan harta gadai dibebani tanggung jawab untuk mengganti kerugian jika harta gadai itu rusak karena kelalaiannya. Karena itu, pemberi gadai dapat menuntut ganti rugi. $^{24}$

Dalam transaksi gadai hutang penerima gadai ditentukan batas akhir waktu pelunasan. Pada saat jatuh tempo, penerima gadai harus memperingatkan pemberi gadai untuk segera melunasi hutangnya. Apabila pemberi gadai tidak dapat melunasi hutangnya maka harta gadai dijual paksa melalui lelang syariah oleh penerima gadai atau pihak ketiga yang telah ditunjuk. Hasil penjualan harta gadai

23 Ibid., Pasal 357. Lihat juga Fatwa Dewan Syariah Nasional Nomor 25/DSN-MUI/III/2002 ..., Loc.Cit.

${ }^{24}$ Peraturan Mahkamah Agung No. 2 Tahun 2008 ..., Op. Cit. Pasal 358, 361-362, 367-369. digunakan untuk melunasi hutang, biaya penyimpanan, dan pemeliharaan yang belum dibayar serta biaya penjualan. Kelebihan hasil penjualan menjadi milik pemberi gadai dan kekurangannya menjadi kewajiban pemberi gadai untuk melunasinya. Pada saat jatuh tempo dan akan dilakukan penjualan harta gadai, sementara itu pemberi gadai tidak diketahui keberadaannya, maka penerima gadai boleh mengajukan kepada pengadilan agar pengadilan menetapkan bahwa penerima gadai boleh menjual harta gadai untuk melunasi utang pemberi gadai. ${ }^{25}$

\section{PENUTUP}

Pelaksanaan akad rahn Pegadaian Syariah cabang Pekanbaru dimulai saat nasabah datang langsung ke Pegadaian Syariah dengan membawa marhun. Kemudian mengisi formulir permintaan jasa penitipan, dan melengkapinya dengan foto copy KTP atau identitas lain yang masih berlaku atau surat kuasa apabila pemilik barang tidak dapat datang sendiri; Petugas menerima, memeriksa, dan menghitung nilai marhun yang akan dititipkan. Berdasarkan taksiran yang dibuat murtahin, maka ditetapkan besarnya biaya jasa yang harus dibayarkan oleh rahin. Nasabah membayar biaya administrasi. Petugas menyimpan barang dengan baik,

\footnotetext{
${ }^{25}$ Ibid., 364-365.
} 
dan menyerahkan surat bukti penyimpanan barang kepada nasabah.

Sejumlah hambatan yang ditemukan dalam akad rahn adalah a) Pembayaran Kurang Lancar dengan sebutan tunggakan hitam dan tunggakan merah. b) Pembiayaan Diragukan yaitu sisa pembiayaan atau pinjaman yang belum atau tidak dibayar setelah lebih dari tiga bulan sejak jatuh tempo lunas, tetapi pembiayaan masih dapat diselamatkan dan agunan bernilai $75 \%$ dari utang nasabah dan Pembiayaan tidak dapat diselamatkan tetapi agunan masih bernilai sekurang-kurangnya $100 \%$ dari utang nasabah. c) Pembiayaan macet yaitu sisa pembiayaan yang tidak memenuhi kriteria lancar, kurang lancar dan diragukan seperti tersebut di atas, atau, Memenuhi kriteria diragukan seperti disebut di atas, tetapi dalam jangka waktu 4 bulan sejak digolongkan diragukan belum

\section{DAFTAR PUSTAKA}

Apriani, Ami. 2010. Prospek Rahn Emas di Perbankan Syariah: Studi Kasus pada Bank Syariah Mandiri, Jakarta: UIN Jakarta, 2010.

Fatwa Dewan Syariah Nasional Nomor 25/DSN-MUI/III/2002 tentang Rahn.

Fatwa Dewan Syariah Nasional Nomor 68/DSN-MUI/III2008 tentang Rahn Tasjily ada pelunasan atau usaha penyelamatan pembiayaan, dan pembiayaan tersebut penyelesaianya melaui prosedur Basyarnas dan bersifat mengikat bagi para pihak.

Kebiasaan dalam transaksi gadai, barang gadai dikuasai oleh penerima gadai. Namun, dalam praktik terdapat juga barang gadai masih tetap dikuasai oleh pemberi gadai. Terkait dengan hal ini DSN telah menetapkan ketentuan akad gadai yang demikian dengan sebutan rahn tasjily, yakni jaminan dalam bentuk barang atas utang tetapi barang jaminan tersebut (marhun) tetap berada dalam penguasaan (pemanfaatan) rahin dan bukti kepemilikannya diserahkan kepada murtahin.

Khairiyah, Masnuatul. 2010. Analisis Perum Pergadaian Syariah Terhadap Loyalitas Konsumen: Studi Pada Pegadaian Syariah cabang Malang, Malang: UIN Maulana Malik Ibrahim, 2010.

Prasetyo, Dodi. 2009. Praktik Akad rahn di Bank BNI Syariah cabang Surabaya, Surabaya: IAIN Sunan Ampel.

Rahmat Syafei. 1995. Konsep Gadai; ArRahn dalam Fikih Islam antara 
Nilai Sosial dan Nilai Komersial dalam Huzaimah T. Yanggo, Problematika Hukum Islam Kontemporer III, Jakarta: Lembaga Studi Islam dan Kemasyarakatan, 1995.

Susilowati, Tri Pudji. 2008. Pelaksanaan Gadai dengan Sistem Syariah di
Perum Pegadaian Semarang, Semarang: Universitas Diponegoro.

Sutan Remi Sjahdeni. 2010. Perbankan Syariah: Produk-produk dan Aspek Hukumnya, Jakarta: Jayakarta Agung Offset, 2010. 